УДК 3.072.:658.71/75

https://doi.org/10.52058/2708-7530-2021-11(17)-70-85

Гольцова Ірина Борисівна аспірантка кафедри теорії та практики управління, Національний технічний університет України «КПІ імені Ігоря Сікорського», вул. Академіка Заболотного , 98, м. Київ, 03187, тел.: (093) 425-87-78, e-mail: iragoltsova2910@gmail.com, https://orcid.org/0000-0002-8026-0253

Волкова Олена Вадимівна студентка другого (магістерського) рівня вищої освіти кафедри теорії та практики управління, Національний технічний університет України «КПІ імені Ігоря Сікорського», вул. Андрія Малишка, 9, м. Київ, 02192, тел: (098) 055-73-42, e-mail: lenokvolkova15@gmail.com

\title{
ІСТОРИЧНА РЕТРОСПЕКТИВА СТАНОВЛЕННЯ ІНСТИТУТУ ПУБЛІЧНИХ ЗАКУПІВЕЛЬ В УКРАЇНІ
}

Анотація. У статті розглянуто становлення сфери публічних закупівель в Україні, а саме 3 періоду іiі незалежності, починаючи с 1991 року і до сьогодення. Проведено грунтовне дослідження історичного контексту становлення інституту публічних закупівель, проведений аналіз з моменту становлення незалежності української держави та до сучасності, продемонстровано поетапне становлення нормативно-правової бази та законодавчого оформлення інституту публічних закупівель.

В сучасних умовах загострення світової економічної кризи та актуалізації існуючих зовнішніх загроз, функціонування системи публічних закупівель постає як один із суттєвих факторів забезпечення сталого розвитку держави, проакцентовано, що існуюча система публічних закупівель $\epsilon$ дієвим механізмом економічного зростання, оскільки саме досконала система закупівельного процесу демонструє результативність державного регулювання та зрілість економіки.

Авторами було охарактеризовано низку нормативно-правових актів, що репрезентували різні епохи щодо способів виконання державного замовлення та забезпечення державних потреб. У межах запропонованої проблематики було розглянуто та представлено рефлексію української наукової спільноти. Також у статті виокремлено роль міжнародного та європейського співтовариства у формування сучасної системи публічних закупівель, охарактеризовано фактори та основні засади, що передували прийняттю Закону України «Про публічні закупівлі» у першій редакції. У роботі окреслені переваги сучасної системи публічних закупівель та визначено напрямки для удосконалення сфери публічних закупівель.

Запропонована авторами проблематика наукового пошуку на сьогодні $\epsilon$ актуальною, оскільки наукова рефлексія у цьому напрямі дослідження $\epsilon$ 
недостатньою, а автори акумулюють у статті ключові державні нормативні документи та акцентують увагу на ключових проблемах, а також пропонують шляхи їх вирішення. Таким чином, продемонстрований авторський аналітичний підхід у дослідженні становлення нормативної бази регулювання публічних закупівель та надані рекомендації подальшого удосконалення.

Ключові слова: публічні закупівлі, державне замовлення, нормативноправове регламентування, державне управління.

Holtsova Iryna Borysivna Graduate student of the Department of Management Theory and Practice of the National Technical University of Ukraine "Igor Sikorsky KPI", Academician Zabolotny St., 98, Kyiv, 03187, tel.: (093) 425-87-78, e-mail: iragoltsova2910@gmail.com, https://orcid.org/0000-0002-8026-0253

Volkova Olena Vadymivna Student of the second (master's) level of higher education of the Department of Management Theory and Practice of the National Technical University of Ukraine "KPI named after Igor Sikorsky", Andriy Malyshko St., 9, Kyiv, 02192, tel: (098) 055-73-42, e-mail: lenokvolkova15@gmail.com

\section{HISTORICAL RETROSPECTIVE OF ESTABLISHMENT OF THE INSTITUTE OF PUBLIC PROCUREMENT IN UKRAINE}

Abstract. The article considers the formation of the sphere of public procurement in Ukraine, namely from the period of its independence, from 1991 to the present. A thorough study of the historical context of the formation of the institute of public procurement, an analysis of the independence of the Ukrainian state and to the present, demonstrated the gradual formation of the legal framework and legislative design of the institute of public procurement.

In the current conditions of aggravation of the global economic crisis and actualization of existing external threats, the functioning of the public procurement system appears as one of the essential factors of sustainable development of the state, the existing public procurement system is an effective mechanism of economic growth regulation and maturity of the economy.

The authors described a number of legal acts that represented different eras in terms of ways to fulfill the state order and meet state needs. Within the framework of the proposed issues, the reflection of the Ukrainian scientific community was considered and presented.

The article also highlights the role of the international and European community in the formation of a modern public procurement system, describes the factors and basic principles that preceded the adoption of the Law of Ukraine "On Public Procurement" in the first edition. The paper outlines the advantages of the modern public procurement system and identifies areas for improving the field of public procurement. 
The issues of scientific research proposed by the authors are relevant today, as scientific reflection in this area of research is insufficient, and the authors accumulate in the article key government regulations and focus on key issues, as well as suggest solutions. Thus, the author's analytical approach in the study of the formation of the regulatory framework for the regulation of public procurement is demonstrated and recommendations for further improvement are provided.

Keywords: public procurement, state order, normative-legal regulation, public administration.

Постановка проблеми. Історичний розвиток українського суспільства загалом формує вектор та траєкторію розвитку сучасної української державності в умовах глобалізаційних тенденцій сьогодення. Розгляд будьякої проблематики стосовно становлення сучасних інституцій репрезентований в українському законодавстві різних періодів розвитку держави. Не виключенням $є$ і сфера державних публічних закупівель, що на сьогодні активно розвивається та реформується в залежності від вимог євроінтеграційних процесів загалом та викликів сучасного суспільства та державотворення. Для того, щоб визначити напрямок дій та надати конструктивний аналіз ситуації сьогодні стосовно державних публічних закупівель варто звернутися до генезису становлення цієї сфери та іiі законодавчого закріплення та висвітлення у різних періодах розвитку України.

Загалом сфера державних публічних закупівель це шлях до становлення відкритого суспільства заснованого на принципах правової держави, оскільки вона покликана на покращення економічного становища держави, запобігання корупційним явищам у державному секторі, дотримання принципів об'єктивності та незаангажованості. Запропонований на сьогодні механізм проведення торгів, електронні ресурси та платформи, що забезпечують реалізацію процесу закупівель $€$ результатом кропіткої роботи та впровадження колосального досвіду як власного так і світової практики і в цілому $\epsilon$ одним 3 найкращих прикладів проведення державних публічних закупівель. Проте, на сьогодні чітко визначений шлях до оптимізації цього процесу та вдосконалення законодавчої бази. Нам вважається доречним надати історичну ретроспективу проблемі держаних публічних закупівель та визначити надбання та прогалини сучасної законодавчої бази стосовно проблеми державних публічних закупівель.

Аналіз останніх досліджень і публікацій. Наукова парадигма сфери державного управління та законодавчої ініціативи репрезентована дослідженнями сфери державних публічних закупівель, а саме різних аспектів ii реалізації - починаючи 3 компетенцій учасників процесу та завершаючи перспективами розвитку, визначенням переваг та недоліків. Проте аналіз саме поетапного становлення публічних закупівель та дослідження генези цього процесу дає змогу оцінити надбання сучасності та окреслити перспективи розвитку, врахувавши помилки та здобутки минулого. Тому в роботі 
репрезентовано дослідження нормативно-правових актів (Закони України, Укази Президента, Постанови Кабінету Міністрів, Розпорядження та Положення), починаючи з 1992 року. Саме аналіз зазначених документів дає можливість автору сформувати власне та об’єктивне уявлення про процес становлення сфери державних публічних закупівель. Проте, наукова рефлексія також представлена і сучасними українськими дослідниками різних галузей знань - політичної,правової, економічної. Проблема генезису державних закупівель представлена також за допомогою праць Л.Г. Удовика (д.юр.н.), розвиток правового регулювання - О.О. Кравчука (д.юр.н.). Дослідження механізму організації публічних закупівель в Україні та країнах Європейського Союзу окреслені в роботах О.Ю. Іванової (д.е.н.) та Г.С. Севостьянової; вектор контролю у сфері державних (публічних) закупівель репрезентований працями М.С. Письменної (к.е.н.). А.І. Миняйло заємається вивченням перспектив розвитку електронних державних закупівель в Україні.

Таким чином, робота побудована на вивченні історичної складової законодавчого процесу України у сфері державних публічних закупівель та грунтується на дослідженнях вітчизняних науковців.

Мета статті полягає у репрезентації історичної ретроспективи розвитку сфери державних публічних закупівель та висвітлення іiі поетапного становлення, а також у аналізі законодавства України стосовно сектору державних публічних закупівель починаючи з 1992 року і до сучасності.

Виклад основного матеріалу. Репрезентація історичного досвіду України стосовно становлення сфери державних публічних закупівель, на нашу думку, є вкрай актуальною проблемою, а їі розгляд та систематизація сприятиме уникненню помилок минулого та висвітлення шляху до якісних перетворень у майбутньому. Прослідковуючи розвиток сфери державних публічних закупівель можна зробити і висновок про становлення економіки країни, вихід їі на новий рівень, прагнення удосконалення законодавства у відповідності 3 євроінтеграційною політикою загалом. Активний законотворчий процес та розвиток сфери публічних закупівель сучасного нам етапу почався в 2014 року, надалі ми детально розглянемо нормативні документи, проте процес державотворення та спроба законодавчого регулювання економіки країни почався ще з 1992 року і цей досвід також є цікавим та корисним для розгляду. Цікавим $\epsilon$ підхід дослідниці М.С. Письменної до хронології висвітлення законодавчого становлення сфери публічних закупівель, а саме: «Аналіз нормативної сфери здійснення державних закупівель дав змогу виділити два основні закони, які діяли протягом останніх років: до прийняття Закону України «Про публічні закупівлі» 2016 року та після [27, с. 196]. Тобто, на думку М.С. Письменної в 2016 році відбулося якісне законодавче перетворення у сфері державних публічних закупівлях, тому на іï думку можна поставити певний рубіж до i 
після прийняття Закону України «Про публічні закупівлі» [3]. Таким чином, ми побудуємо хронологію законодавчої ініціативи та виокремимо переваги та недоліки становлення сфери державних публічних закупівель починаючи 3 1992 року і до сьогодні.

Становлення української державності в 90-ті роки XX століття відбувалося у вкрай складних історичних умовах та вимагало власної самоідентифікації, відокремлення та обгрунтування всіх соціальних та державних інституцій. 3 набуттям України незалежності, долучення до ринкових відносин починається активне становлення сектору державних закупівель та його законодавчого обгрунтування та реалізації.

Першим нормативним документом, що регулював сферу державних закупівель став Наказ Міністерства зовнішніх економічних зв'язків і торгівлі України № 70 від 01 жовтня 1992 року, який вводив у дію Положення про порядок підготовки, організації та проведення міжнародних торгів (тендерів) на території України [25] (Положення відмінено згідно Наказу Міністерства економіки, європейської інтеграції № 286 від 26.11.2001 року [26]). Даний документ вперше охарактеризував сферу державних закупівель, надав визначення термінам та запровадив процес здійснення державних закупівель враховуючи демократичні принципи та світові вимоги стовно ринкових відносин та здійснення економічної діяльності. Пізніше дане Положення було також закріплене Постановою Кабінету Міністрів України від 21 жовтня 1993 р. № 871 «Про затвердження Положення про порядок організації та проведення міжнародних торгів (тендерів) в Україні [16]. Вказаний документ мав багато суттєвих недоліків, проте вперше мав на меті вивести Україну на світовий рівень у якості повноправного партнера. Дане Положення визначало порядок підготовки, організації та проведення міжнародних торгів (тендерів) щодо реалізації різноманітних проектів співробітництва на території України за рахунок усіх джерел фінансування.

Зазначене Положення мало новаторський характер, оскільки до його затвердження мови не могло бути про відкриті торги та тим паче про залучення до торгів іноземних комерційних підприємств. Положення регламентувало сферу державних закупівель та надало підгрунтя для розвитку здорової конкуренції, можливості вибору оптимальних економічних умов. Також було охарактеризовано різновиди торгів, визначено та прописано необхідність створення тендерних комітетів, перелік вимог до них, окреслені вимоги для надавачів тендерних пропозицій інше. Тобто, дане Положення мало на меті створення конкурентного середовища та як наслідок формування умов для досягнення найбільшої ефективності, можливості до зменшення цін та якісним перетворенням у сфері державних закупівель.

Проте, варто зазначити, що вказаний документ містив і ряд суттєвих недоліків, що вимагали усунення та оптимізації, а саме Положення регламентувало діяльність процесу ведення торгів лише 3 іноземними постачальниками товарів та послуг, тобто було націлене на міжнародне 
співробітництво і регулювало відносини для залучення іноземних постачальників. Також були важливі недоліки у формування тендерної документації та процедура обрання переможця не мала прозорого характеру. Тобто, не було чіткої регламентації діяльності процесу торгів і як наслідок формувалося ситуація заангажованості тендерних комітетів та обрання переможців, що не відповідали заявленим цілям, також проведення торгів не визначалося обов’язковою процедурою та чітко не регламентувало випадки їх проведення.

Таким чином, склалася ситуація, за якої Україна дотримувалася міжнародно прийнятих засад проведення державних торгів на конкурсній основі лише для іноземних постачальників/підрядників. Окреслений підхід сприяв залученню іноземних інвестицій, товарів та послуг, а от на території України державні підприємства керувалися старою радянської системою проведення та реалізації державного замовлення, що суперечило розвитку стратегії реалізації механізмів ринкової економіки.

Важливими документами, що регламентували сферу державного замовлення на товари та послуги стали Розпорядження Кабінету Міністрів України № 735 від 9 листопада 1992 року та Постанова Кабінету Міністрів України № 400 «Про Концепцію державного замовлення» від 21 липня 1992 року [21], яка затвердила концепцію державного замовлення та визначила, що публічні закупівлі $\epsilon$ складовою частиною системи економічних методів державного регулювання. Зазначена постанова стала доповненням до Указу Президента 289/92 «Про державне замовлення в Україні» від 04 травня 1992 року(далі - Указ) [10], а саме в аспекті тлумачення процедури розміщення державних замовлень, яка не була висвітлена в даному документі. Указ цікавий нам також 3 позиції першого тлумачення категорії «державного замовлення», а саме як «складової частини системи економічних методів державного регулювання на період переходу до ринкових відносин і розвитку ринкової інфраструктури» [10]. Документом, що визначив сферу розрахунку за послуги стало Розпорядження Кабінету Міністрів України № 735 від 9 листопада 1992 року, що регламентувало систему розрахунків між замовником та постачальником товарів та послуг [14].

Подальший розвиток законодавчих документів не демонстрував суттєвого розвитку та усунень важливих недоліків, проте варто зазначити ряд нормативно-правових актів, які вносили певні уточнення у здійснення державного замовлення, а саме Постанову Кабінету Міністрів України №100 «Про порядок укладання державного контракту i формування державного замовлення на 1993 рік» від 10 лютого1993 року [22] та Указ Президента України №489/93 «Про державний контракт і державне замовлення на 1994 рік» від 28 жовтня 1993 року [11]. Згідно цих документів встановлювалося, що процедура конкурсу застосовується за наявності можливості вибору виконавців та регламентувався жорсткий характер прийняття державного замовлення і державного контракту. Було визначено ряд підприємств для яких 
державне замовлення є обов'язковим, а для яких укладання державного контракту та прийняття державного замовлення має добровільний характер.

Важливим кроком на шляху до створення відкритого економічного простору та запровадження світового досвіду господарювання стала Постанова № 312 Кабінету Міністрів України «Про порядок організації закупівель продукції для державних потреб» від 28 квітня 1995 року [20], згідно якої запроваджувалася конкурсна процедура здійснення державного замовлення. Проте, суттєвим фактом $є$ те, що сама процедура проведення конкурсу чітко не регламентувалася та не була прописана, тому постало питання про порядок проведення таких конкурсів та механізм їх реалізації. Документом, що мав пролити світло на процедуру проведення конкурсу у сфері державного замовлення мав стати Закон України «Про поставки продукції для державних потреб» від 22 грудня 1995 року [9], проте вказаний нормативно-правовий акт регламентував лише порядок поставки продукції та не визначав умови конкурсу та процедурні аспекти реалізації діяльності суб’єктів господарювання.

Таким чином, розвиток української державності та долучення України до світової торгівлі, ринкової економіки тісно пов’язане з розвитком системи державного замовлення або сфери державних публічних закупівель. Саме бурхливий розвиток світу, глобалізаційні тенденції розвитку ринку вимагали від України постановки та вирішення проблем законодавчого регулювання сфери державних закупівель, які мали відповідати загальноприйнятим світовим критеріям та нормам. Розвиток економіки держави став тісно пов'язаним 3 необхідністю приєднання до світових економічних спільнот та організацій. Важливим моментом стало приєднання України до Світової організації торгівлі (далі - СОТ) що сталося 15 квітня 1994 року. Можливість даного кроку була тісно пов'язана 3 необхідністю реформування та доповнення внутрішнього законодавства стосовно сфери державного замовлення, оскільки законодавча база була вкрай не досконала та не регламентувала і не впроваджувала новітні міжнародні практики реалізації державного замовлення. Вимоги СОТ, зокрема і що стосувалися державних закупівель були реалізовані та враховані в Угоді про державні закупівлі СОТ (далі - Угода), прийнятій у квітні 1994 року. Основними вимогами СОТ, які були віддзеркалені в Угоді, були:

- поширюється на будь-який закон, норму чи практику, що стосуються державних закупівель, включаючи державні закупівлі у сфері послуг;

- відсутність дискримінації постачальників, залежно від їх статусу та державної належності;

- здійснення закупівель на конкурсній основі із забезпеченням прозорості на кожній стадії торгів (тендерів) на вимогу будь-кого з постачальників [29, с.16].

Тому, для реалізації вказаних вимог СОТ були прийняті у 1997-1998 роках Постанова Кабінету Міністрів України № 694 «Про організацію та проведення торгів (тендерів) у сфері державних закупівель товарів (робіт, 
послуг)» від 28 червня1997 року [19] (далі - Постанова № 694) та Постанова № 1058 «Про створення єдиної системи закупівель товарів (робіт, послуг) за рахунок коштів державного бюджету та іноземних кредитів, що залучаються під гарантії Кабінету Міністрів України» [18] (далі - Постанова № 1058) від 24 вересня 1997 року.

Вказані документи регламентували певні аспекти проведення державних закупівель, а саме Постанова № 694: «Загальні процедури здійснення державних закупівель центральними та місцевими органами виконавчої влади, підприємствами, установами, організаціями незалежно від форми власності, що здійснюють закупівлю продукції за рахунок коштів державного бюджету або іноземних кредитів, що залучаються під гарантію Кабінету Міністрів України шляхом проведення торгів (тендерів)» [19]. Що ж стосується Постанови № 1058, то iï прийняття пов’язане 3 регламентуванням та обмеженням проведення процедури закупівель «товарів, робіт, послуг вартістю понад 10000 гривень, шляхом встановлення єдиного для державних структур всіх рівнів порядку здійснення закупівель та контролю за використанням коштів державного бюджету» [18].

Слід підсумувати, що, в цілому, правила проведення державних закупівель, закріплені в описаних документах, задовольняли світове співтовариство та їх в'явилося достатньо для міжнародного партнерства. Проте, регламентація та регулювання процесу закупівель, аспект відповідальності сторін вимагало законодавчого закріплення та більш чіткого визначення вимог до проведення конкурсу та визначення реалізації державного замовлення через проведення процедури конкурсу обов'язковим для всіх суб'єктів державного господарювання. Також окремого регулювання вимагали певні державні інституції, були прийняті додаткові нормативноправові акти, що регламентували державні закупівлі у сфері медицини, армії, державного будівництва (Законом України «Про державне оборонне замовлення» від 03 березня1999 року [6], Постанова Кабінету Міністрів України №2244 «Питання державного оборонного замовлення» від 9 грудня 1999 року [17], інше). Проте вони мали чинність в межах певної ситуації та нетривалого періоду часу.

Наступним важливим кроком у розвитку державних публічних закупівель стало прийняття 22 лютого 2000 року Закону України «Про закупівлю товарів, робіт і послуг за державні кошти» (далі - Закон) [7]. Метою цього Закону є «створення конкурентного середовища у сфері державних закупівель, а також запобігання проявам корупції у цій сфері, забезпечення прозорості процедур закупівель товарів, робіт i послуг за державні кошти та досягнення оптимального і раціонального їх використання» [7]. Закон втратив чинність, згідно Закону України «Про визнання таким, що втратив чинність, Закону України «Про закупівлю товарів, робіт і послуг за державні кошти» від 23 березня 2008 року [5], деякі його положення були визнані такими, що 
суперечать умовам співробітництва України з СОТ та не відповідають Конституції України. Також вказаний Закон визначав порогові величини сум для проведення торгів у сфері державного замовлення і відповідно вимагав подачі звітності про виконання робіт, послуг або закупівлю товарів. Важливо відмітити, що певного розвитку набули і категорії, що характеризують учасників торгів, а в пізніших редакціях Закону у 2003 році відбулися суттєві зміни, а саме «виконавець» було замінено на «учасник».

Після того, як 22 лютого 2000 року втратив чинність Закон України «Про закупівлю товарів, робіт і послуг за державні кошти» [7], було прийняте тимчасове положення, що регулювало сферу державного замовлення. Постанова № 274 Кабінету Міністрів України від 28 березня 2008 року [23] затвердила Тимчасове положення про закупівлю товарів, робіт і послуг за державні кошти, однак рішенням Конституційного Суду України № 22-рп/2008 від 09 жовтня 2008 року Постанову Кабінету Міністрів України від 28 березня 2008 № 274 «Про здійснення закупівель товарів, робіт і послуг за державні кошти» [23] було визнано такою, що не відповідає Конституції України [1]. Після такого рішення було прийнято ще декілька постанов, проте вони так і не набирали чинності 3 різних причин, тому сфера державних закупівель або державного замовлення залишалася довгий час нерегульованою що призвело до зростання корупційних явищ, законодавчого маніпулювання підприємствами та іншими учасниками торгів умовами конкурсу.

Ситуація дещо покращилася, коли постало питання про отримання фінансової допомоги від Світового банку, а саме Третьої позики на політику розвитку, фінансовий транш був можливий лише у випадку чіткого регулювання сфери державного замовлення, юридичного обгрунтування та регламентації процедури співробітництва із іноземними організаціями та установами. Тому Міністерство економіки підготувало нову редакцію Положення про закупівлю товарів, робіт і послуг за державні кошти (далі Положення), яка була затверджена Постановою № 1017 Кабінету Міністрів України від 19 листопада 2008 року [24]. Положення було погоджене 3 експертами Світового банку та стало основним фактом в отриманні України фінансової допомоги для підтримки інституційних та стратегічних реформ Уряду.

Таким чином, склалася ситуація, що сама держава не була зацікавлена в чіткому регламентуванні процесу здійснення та реалізації державного замовлення, проте світові глобалізаційні процеси, вихід країни на світовий ринок, можливість отримання фінансових дотацій та виконання вимог Світових співтовариств та партнерів згенерувало потребу все ж таки законодавчого чіткого прописання та регулювання процесу державних закупівель. Вагомим кроком стало прийняття Закону України «Про здійснення державних закупівель» 01 червня 2010 року [8] (далі - Закон). Здобутки системи публічних державних закупівель сьогодні детерміновані саме 
визначенням стратегії розвитку цієї сфери починаючи з 2010 року. Зазначений Закон має низку позитивних моментів та став якісно новим кроком на шляху до реалізації європейського розвитку України як рівноправного партнера та перспективної демократичної країни. Позитивні аспекти полягають, в першу чергу, у спрощенні системи державних закупівель, чіткій регламентації роботи тендерних комітетів із зазначенням вимог до учасників та створення останнього, визначив систему оскарження рішень та проведення торгів через спеціальну систему закупівель.

3 цього моменту почалося якісне становлення сфери державних публічних закупівель, далі були прийняті низка нормативно-правових актів, що були покликані на гармонізацію відносин Свропейського Союзу (далі ЄC) та України, дані документи були прийняті у межах спільного проекту з СС «Гармонізація системи державних закупівель в Україні зі стандартами СС». Визначеною метою роботи проекту стало «здійснення внеску у розвиток сталого і послідовного управління державними фінансами, шляхом створення всеосяжної і прозорої нормативно-правової бази для здійснення державних/публічних закупівель, ефективної інституційної інфраструктури для здійснення державних/публічних закупівель, а також забезпечення підзвітності та цілісності органів державної влади в сфері закупівель та розвитку системи державної допомоги в Україні» [30]. Таким чином робота у межах проекту дала позитивний результат та сприяла спочатку внесенню змін до діючого закону (20 квітня 2014 року) та врешті прийняття Закону України «Про публічні закупівлі» 15 грудня 2015 року [3]. Такі рішення ознаменували створення однієї 3 найкращих в Європі процедури проведення державних публічних закупівель та створення вкрай ефективної електронної платформи «Прозорро» для реалізації процедури державних закупівель. В результаті всі закупівлі, що реалізуються через державний бюджет мають проходити лише в межах електронної системи.

Реформування системи державного управління в України відбувається у вкрай складних соціально-політичних умовах - це і системні економічні кризи, i військове протистояння на Сході, i реформування не лише економікоправової сфери, а й соціальної. Тому прийняття в 2015 році Закону України «Про публічні закупівлі» (далі - Закон) ознаменувало визначення якісного вектору розвитку у сфері боротьби з корупцією, прозорість витрат державного бюджету, прагнення до чесності, прозорості, однаковим можливостей для всіх учасників сфери державних закупівель та представників бізнесу. На сьогодні Закон має численну кількість змін та доповнень по відношенню до 2015 року, проте не втратив чинності. Останні зміни були внесені 17 березня 2020 року та стосувалися жахливої вірусної загрози, боротьба з якою вимагає рішучого державного керування та спрощеної системи державних закупівель без проведення конкурсу для ряду державних установ, зокрема медичних.

Висновки. Таким чином, ми прослідкували генезис становлення сфери 
державних публічних закупівель від 1992 року та до сьогодення. Автором був проведений грунтовний аналіз поетапного запровадження якісних змін для того, щоб сьогодні Україна мала одну з найкращих електронних систем реалізації державних закупівель. Розглядаючи історичну ретроспективу становлення державного управління слід виокремити тенденцію до саме європейського шляху розвитку та реалізацію досвіду саме європейських стратегій розвитку не лише у сфері державних закупівель. Після здобуття Україною незалежності, держава одразу визначила необхідність залучення світових партнерів та актуалізацію міжнародного партнерства, зокрема і у сфері торгівлі та постачання послуг. Як нами зазначалося раніше до 2008 року всі нормативно-правові акти, що були прийняті мали на меті саме залучення іноземних інвесторів та відкриття нових можливостей для рівноправної співпраці з світовою спільнотою. Це і заключення договорів з СОТ та проект співпраці 3 ЄС. Саме необхідність відповідності високим вимогам європейських країн Україна шляхом законодавчої ініціативи, можливих помилок та здобутків створила такий сектор державних публічних закупівель, який, на сьогодні може бути прикладом для багатьох та $є$ результатом імплементації і досвіду зарубіжних партнерів.

Діючий на сьогодні Закон України «Про публічні закупівлі» від 1 квітня 2016 року має багато сильних сторін, проте існують аспекти, які вимагають певного вдосконалення. робота по створенню оптимальних вимог та умов реалізації державних закупівель триває весь час та реалізується у змінах та доповнення, зазначені у тексті роботи останні зміни стосуються надзвичайної ситуації в країні, проте зміни, які мають набрати чинності 20 квітня 2020 року стосуються процедурних моментів та термінів подання документів до участі у конкурсі та певних моментів оголошення переможців, оприлюднення та оскарження результатів конкурсу, умов роботи тендерних комітеті та уповноважених осіб. Тобто, робота над покращенням проведення державних публічних закупівель триває та вимагає невпинного доопрацювання, щоб обгрунтовано відповідати викликам сьогодення.

\section{Лimepamypa:}

1. Конституція України. Відомості Верховної Ради України (ВВР), 1996, № 30, ст. 141. URL: https://zakon.rada.gov.ua/laws/show/254\%D0\%BA/96-\%D0\%B2\%D1\%80\#Text.

2. Закон України «Про здійснення державних закупівель» від 10 квітня 2014 року № 1197-VII. URL: http://zakon2.rada.gov.ua/laws/show/1197-18.

3. Закон України «Про публічні закупівлі» від 25 грудня 2015 року № 922-VIII. URL: http://zakon2.rada.gov.ua/laws/show/922-19.

4. Закон України «Про державне замовлення для задоволення пріоритетних державних потреб». № 493/95 від 22 грудня 1995 року. URL: https://zakon.rada.gov.ua/ laws/show/493/95\%D0\%B2\%D1\%80/ed20040101/sp:java-:max100.

5. Закон України «Про визнання таким, що втратив чинність Закону України «Про закупівлю товарів, робіт і послуг за державні кошти». № 150-VI від 23 березня 2008 року. URL: https://zakon.rada.gov.ua/laws/show/150-17\#Text. 
6. Закон України «Про державне оборонне замовлення» № 464-XIV від 03 березня 1999 року. URL: https://zakon.rada.gov.ua/laws/show/464-14

7. Закон України «Про закупівлю товарів, робіт і послуг за державні кошти» № 1490III від 22 лютого 2000 року. URL: https://zakon.rada.gov.ua/laws/show/1490-14.

8. Закон України «Про здійснення державних закупівель» № 2289 від 01 червня 2010 року. URL: https://zakon.rada.gov.ua/laws/show/2289-17.

9. Закон України «Про поставки продукції для державних потреб» N 01-8/110 від 12.03.96. URL: https://zakon.rada.gov.ua/laws/show/v_110800-96\#Text.

10. Указ Президента України «Про державне замовлення в Україні» № 289/92 від 04 травня 1992 року. URL: https://zakon.rada.gov.ua/laws/show/289/92

11. Указ Президента України «Про державний контракт і державне замовлення на 1994 рік» № 489/93 від 01 січня 1994 року. URL: https://zakon.rada.gov.ua/laws/show/489/93

12. Розпорядження Кабінету Міністрів України «Про реалізацію пілотного проекту щодо впровадження процедури електронних закупівель товарів» від 20 травня 2015 року № 501-p. URL: http://zakon2.rada.gov.ua/laws/show/501-2015-\%D1\%80.

13. Розпорядження Кабінету Міністрів України «Про проведення експерименту iз застосування електронних засобів під час здійснення переговорної процедури закупівлі: від 31 березня 2015 року» № 416-p URL: http://www.kmu.gov.ua/control/uk/cardnpd?docid=248135046.

14. Розпорядження Кабінету Міністрів України «Про затвердження переліку продукції та сировини, що імпортується державними підприємствами 3 держав - республік колишнього Союзу $\mathrm{PCP}_{\Downarrow}$ № 735-p від 9 листопада 1992 року. URL: https://zakon.rada.gov.ua/laws/show/735-92-\%D1\%80

15. Постанова Кабінету Міністрів України «Про затвердження Порядку функціонування електронної системи закупівель та проведення авторизації електронних майданчиків: від 24 лютого 2016 року» № 166 URL: http://zakon2.rada.gov.ua/laws/show/1662016-\%D0\%BF.

16. Постанова Кабінету Міністрів України «Про затвердження Положення про порядок організації та проведення міжнародних торгів (тендерів) в Україні» від 21 жовтня 1993 p. № 871. URL: https://zakon.rada.gov.ua/laws/show/871-93-\%D0\%BF .

17. Постанова Кабінету Міністрів України «Питання державного оборонного замовлення» від 9 грудня 1999 р. № 2244. URL: https://zakon.rada.gov.ua/laws/show/2244-99-\%D0\%BF.

18. Постанова Кабінету Міністрів України «Про створення єдиної системи закупівель товарів (робіт, послуг) за рахунок коштів державного бюджету та іноземних кредитів, що залучаються під гарантії Кабінету Міністрів України» № 1058 від 24 вересня 1997 p. URL: https://zakon.rada.gov.ua/laws/show/1058-97-\%D0\%BF.

19. Постанова Кабінету Міністрів України «Про організацію та проведення торгів (тендерів) у сфері державних закупівель товарів (робіт, послуг)» № 694 від 28 червня 1997 р. URL: https://zakon.rada.gov.ua/laws/show/694-97-\%D0\%BF.

20. Постанова Кабінету Міністрів України «Про порядок організації закупок продукції для державних потреб» № 312 від 28 квітня 1995 p. URL: https://zakon.rada.gov.ua/laws/show/312-95-\%D0\%BF.

21. Постанова Кабінету Міністрів України «Про Концепцію державного замовлення» № 400 від 21 липня 1992 p. URL: https://zakon.rada.gov.ua/laws/show/400-92-\%D0\%BF.

22. Постанова Кабінету Міністрів України «Про порядок укладання державних контрактів і формування державного замовлення на 1993 рік» № 100 від 10 лютого 1993 року. URL: https://zakon.rada.gov.ua/laws/show/10093\%D0\%BF/ed19960529/find?text=\%C4\% E5\%F0\%E6\%E0\%E2\%ED\%E8\%E9+\%EA\%EE\%ED\%F2\%F0\%E0\%EA\%F2.

23. Постанова Кабінету Міністрів України «Про здійснення закупівель товарів, робіт і послуг за державні кошти» № 274 від 28 березня 2008 року. URL: https://zakon.rada.gov.ua/laws/show/274-2008-\%D0\%BF. 
24. Постанова Кабінету Міністрів України «Про внесення змін до Положення про закупівлю товарів, робіт і послуг за державні кошти» № 1017 від 19 листопада 2008 року. URL: https://zakon.rada.gov.ua/laws/show/1017-2008-\%D0\%BF.

25. Наказ Міністерства зовнішніх економічних зв'язків і торгівлі України «Положення про порядок підготовки, організації та проведення міжнародних торгів (тендерів) на території України» від 01 жовтня 1992 року № 70. URL: http://search.ligazakon.ua/__ doc2.nsf/link1/FIN1811.html.

26. Наказ Міністерства економіки та 3 питань європейської інтеграції України «Про внесення змін до деяких наказів з питань державних закупівель» № 286 від 26 листопада 2001 року. URL: http://search.ligazakon.ua/l_doc2.nsf/link1/REG6220.html.

27. Письменна М.C. Парадигмальний підхід до контролю в сфері державних (публічних) закупівель. Науковий вісник Херсонського державного університету. Серія Економічні науки. Вип.25 Частина 1. 2017. С. 194198

28. Малолітнева В.К. Ліллемяе О.Е. Горизонтальні цілі у публічних закупівлях як додаткова підстава для оцінки на відповідність правилам державної допомоги. Проблеми законності. Вип.144. 2019. 353 с.

29. Державне регулювання закупівель в умовах реалізації адміністративної реформи. Івано-Франківський центр науки, інноващій та інформатизаџії. Івано-Франківськ, 2012. С. 138.

30. Жуков М.С. Удовика Л.Г. Генезис інституту публічних закупівель в Україні. Актуальні проблеми реформування сучасного законодавства (м. Львів, 27-28 жовтня 2017 р.). 2017. C. 7-10.

31. Кравчук А.О. Развитие правового регулирования в сфере государственной собственности в Украине (управленческий аспект). Вестник ТГУ. Гуманитарные науки. Право. Выпуск 4 (120). 2013. С. 376-382.

\section{References:}

1. Konstitucija Ukraïni [The Constitution of Ukraine]. (n.d.). zakon.rada.gov.ua. Retrieved from https://zakon.rada.gov.ua/laws/show/254\%D0\%BA/96-\%D0\%B2\%D1\%80\#Text [in Ukrainian].

2. Zakon Ukraïni «Pro zdijsnennja derzhavnih zakupivel'» [The Law of Ukraine «On Public Procurement»]. (n.d.). zakon.rada.gov.ua. Retrieved from http://zakon2.rada.gov.ua/laws/ show/1197-18. [in Ukrainian].

3. Zakon Ukraïni «Pro publichni zakupivli" [The Law of Ukraine «On Public Procurement»]. (n.d.). zakon.rada.gov.ua. Retrieved from http://zakon2.rada.gov.ua/laws/show/ 922-19. [in Ukrainian].

4. Zakon Ukraïni «Pro derzhavne zamovlennja dlja zadovolennja prioritetnih derzhavnih potreb» [The Law of Ukraine « On State Procurement to Meet Priority State Needs»]. (n.d.). zakon.rada.gov.ua. Retrieved from https://zakon.rada.gov.ua/laws/show/493/95\%D0\%B2\% D1\%80/ed20040101/sp:java-:max100. [in Ukrainian].

5. Zakon Ukraïni «Pro viznannja takim, shho vtrativ chinnist' Zakonu Ukraïni «Pro zakupivlju tovariv, robit i poslug za derzhavni koshti» [The Law of Ukraine « Law of Ukraine "On Recognition of the Law of Ukraine" On Procurement of Goods, Works and Services for Public Funds "»]. (n.d.). zakon.rada.gov.ua. Retrieved from https://zakon.rada.gov.ua/laws/show/15017\#Text.. [in Ukrainian].

6. Zakon Ukraïni «Pro derzhavne oboronne zamovlennja» [The Law of Ukraine « On the State Defense Order»]. (n.d.). zakon.rada.gov.ua. Retrieved from https://zakon.rada.gov.ua/ laws/show/464-14. [in Ukrainian].

7. Zakon Ukraïni «Pro zakupivlju tovariv, robit i poslug za derzhavni koshti» [The Law of Ukraine « On Procurement of Goods, Works and Services for State Funds»]. (n.d.). zakon.rada.gov.ua. Retrieved from https://zakon.rada.gov.ua/laws/show/1490-14.[in Ukrainian]. 
8. Zakon Ukraïni «Pro zdijsnennja derzhavnih zakupivel'» [The Law of Ukraine « On Public Procurement»]. (n.d.). zakon.rada.gov.ua. Retrieved https://zakon.rada.gov.ua/laws/show/228917.in Ukrainian].

9. Zakon Ukraïni «Pro postavki produkciï dlja derzhavnih potreb» [The Law of Ukraine « On supplies of products for state needs»]. (n.d.). zakon.rada.gov.ua. Retrieved https://zakon.rada.gov.ua/laws/show/v_110800-96\#Text [in Ukrainian].

10. Ukaz Prezidenta Ukraïni «Pro derzhavne zamovlennja v Ukraïni». [Decree of the President of Ukraine "On the state order in Ukraine"]. (n.d.). zakon.rada.gov.ua. Retrieved https://zakon.rada.gov.ua/laws/show/289/92 [in Ukrainian].

11. Ukaz Prezidenta Ukraïni «Pro derzhavnij kontrakt i derzhavne zamovlennja na 1994 rik». [Decree of the President of Ukraine "On the state contract and state order for 1994"]. (n.d.). zakon.rada.gov.ua. Retrieved: https://zakon.rada.gov.ua/laws/show/489/93 [in Ukrainian].

12. Rozporjadzhennja Kabinetu Ministriv Ukraïni «Pro realizaciju pilotnogo proektu shhodo vprovadzhennja proceduri elektronnih zakupivel' tovariv» [Order of the Cabinet of Ministers of Ukraine "On the implementation of a pilot project to implement the procedure of electronic procurement of goods"]. (n.d.). zakon.rada.gov.ua. Retrieved: http://zakon2.rada.gov.ua/laws/ show/501-2015-\%D1\%80 [in Ukrainian].

13. Rozporjadzhennja Kabinetu Ministriv Ukraïni «Pro provedennja eksperimentu iz zastosuvannja elektronnih zasobiv pid chas zdijsnennja peregovornoï proceduri zakupivli» [Order of the Cabinet of Ministers of Ukraine "On conducting an experiment on the use of electronic means during the negotiated procurement procedure"]. (n.d.). kmu.gov.ua Retrieved: http://www.kmu.gov.ua/control/uk/cardnpd?docid=248135046 [in Ukrainian].

14. Rozporjadzhennja Kabinetu Ministriv Ukraïni «Pro zatverdzhennja pereliku produkciï ta sirovini, shho importuєt'sja derzhavnimi pidpriemstvami z derzhav - respublik kolishn'ogo Sojuzu RSR» [Order of the Cabinet of Ministers of Ukraine "On approval of the list of products and raw materials imported by state enterprises from the states - republics of the former USSR"]. (n.d.). zakon.rada.gov.ua. Retrieved: https://zakon.rada.gov.ua/laws/show/735-92-\%D1\%80 [in Ukrainian].

15. Postanova Kabinetu Ministriv Ukraïni «Pro zatverdzhennja Porjadku funkcionuvannja elektronnoï sistemi zakupivel' ta provedennja avtorizaciï elektronnih majdanchikiv» [Resolution of the Cabinet of Ministers of Ukraine "On approval of the Procedure for the functioning of the electronic procurement system and authorization of electronic platforms]. (n.d.). zakon.rada.gov.ua. Retrieved: http://zakon2.rada.gov.ua/laws/show/166-2016-\%D0\%BF. [in Ukrainian].

16. Postanova Kabinetu Ministriv Ukraïni «Pro zatverdzhennja Polozhennja pro porjadok organizaciï ta provedennja mizhnarodnih torgiv (tenderiv) v Ukraïni» [Resolution of the Cabinet of Ministers of Ukraine "On approval of the Regulations on the organization and conduct of international tenders (tenders) in Ukraine"]. (n.d.). zakon.rada.gov.ua. Retrieved https://zakon.rada.gov.ua/laws/show/871-93-\%D0\%BF. [in Ukrainian].

17. Postanova Kabinetu Ministriv Ukraïni «Pitannja derzhavnogo oboronnogo zamovlennja» [Resolution of the Cabinet of Ministers of Ukraine "Issues of State Defense Order"]. (n.d.). zakon.rada.gov.ua. Retrieved https://zakon.rada.gov.ua/laws/show/2244-99-\%D0\%BF. [in Ukrainian].

18. Postanova Kabinetu Ministriv Ukraïni «Pro stvorennja єdinoï sistemi zakupivel' tovariv (robit, poslug) za rahunok koshtiv derzhavnogo bjudzhetu ta inozemnih kreditiv, shho zaluchajut'sja pid garantiï Kabinetu Ministriv Ukraïni» [Resolution of the Cabinet of Ministers of Ukraine "On the establishment of a unified system of procurement of goods (works, services) at the expense of the state budget and foreign loans under the guarantee of the Cabinet of Ministers of Ukraine"]. (n.d.). zakon.rada.gov.ua. Retrieved https://zakon.rada.gov.ua/laws/show/1058-97$\%$ D0\%BF. [in Ukrainian].

19. Postanova Kabinetu Ministriv Ukraïni «Pro organizaciju ta provedennja torgiv (tenderiv) u sferi derzhavnih zakupivel' tovariv (robit, poslug)» [Resolution of the Cabinet of Ministers of

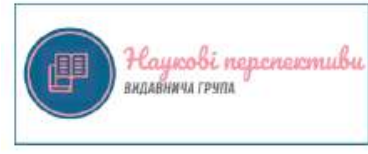


Ukraine "On the organization and conduct of tenders (tenders) in the field of public procurement of goods (works, services)"]. (n.d.). zakon.rada.gov.ua. Retrieved https://zakon.rada.gov.ua/ laws/show/694-97-\%D0\%BF [in Ukrainian].

20. Postanova Kabinetu Ministriv Ukraïni «Pro porjadok organizaciï zakupok produkciï dlja derzhavnih potreb» [Resolution of the Cabinet of Ministers of Ukraine "On the procedure for organizing procurement of products for state needs"]. (n.d.). zakon.rada.gov.ua. Retrieved https://zakon.rada.gov.ua/laws/show/312-95-\%D0\%BF. [in Ukrainian].

21. Postanova Kabinetu Ministriv Ukraïni «Pro Koncepciju derzhavnogo zamovlennja» [Resolution of the Cabinet of Ministers of Ukraine "On the Concept of State Procurement"]. (n.d.). zakon.rada.gov.ua. Retrieved https://zakon.rada.gov.ua/laws/show/400-92-\%D0\%BF. [in Ukrainian].

22. Postanova Kabinetu Ministriv Ukraïni «Pro porjadok ukladannja derzhavnih kontraktiv i formuvannja derzhavnogo zamovlennja na 1993 rik»" " [Resolution of the Cabinet of Ministers of Ukraine "On the procedure for concluding state contracts and forming a state order for 1993"]. (n.d.). zakon.rada.gov.ua. Retrieved https://zakon.rada.gov.ua/laws/show/10093\%D0\%BF/ ed19960529/ find?text=\%C4\%E5\%F0\%E6\%E0\%E2\%ED\%E8\%E9+\%EA\%EE\%ED\%F2\%F0\%E0\%EA\%F2. [in Ukrainian].

23. Postanova Kabinetu Ministriv Ukraïni «Pro zdijsnennja zakupivel' tovariv, robit i poslug za derzhavni koshti» [Resolution of the Cabinet of Ministers of Ukraine "On the procedure for concluding state contracts and forming a state order for 1993"]. (n.d.). zakon.rada.gov.ua. Retrieved https://zakon.rada.gov.ua/laws/show/274-2008-\%D0\%BF [in Ukrainian].

24. Postanova Kabinetu Ministriv Ukraïni «Pro vnesennja zmin do Polozhennja pro zakupivlju tovariv, robit i poslug za derzhavni koshti» [Resolution of the Cabinet of Ministers of Ukraine "On Amendments to the Regulations on Procurement of Goods, Works and Services for State Funds"]. (n.d.). zakon.rada.gov.ua. Retrieved : https://zakon.rada.gov.ua/laws/show/10172008-\%D0\%BF [in Ukrainian].

25. Nakaz Ministerstva zovnishnih ekonomichnih zv'jazkiv i torgivli Ukraïni «Polozhennja pro porjadok pidgotovki, organizaciï ta provedennja mizhnarodnih torgiv (tenderiv) na teritorii Ukraïni» [Order of the Ministry of Foreign Economic Relations and Trade of Ukraine "Regulations on the procedure for preparation, organization and conduct of international tenders (tenders) on the territory of Ukraine"]. (n.d.). search.ligazakon.ua. Retrieved : http://search.ligazakon.ua/1_doc2.nsf/link1/FIN1811.html.[in Ukrainian].

26. Nakaz Ministerstva ekonomiki ta z pitan' evropejs'koï integraciï Ukraïni «Pro vnesennja zmin do dejakih nakaziv z pitan' derzhavnih zakupivel'» [Order of the Ministry of Economy and European Integration of Ukraine "On Amendments to Certain Orders on Public Procurement"]. (n.d.). search.ligazakon.ua. Retrieved : http://search.ligazakon.ua/l_doc2.nsf/link1/REG6220.html.[in Ukrainian].

27. Pis'menna, M.S. (2017).Paradigmal'nij pidhid do kontrolju v sferi derzhavnih (publichnih) zakupivel [Paradigmatic approach to control in the field of public (public) procurement]. Naukovij visnik Hersons'kogo derzhavnogo universitetu. Serija Ekonomichni nauki Scientific Bulletin of Kherson State University. Economic Sciences Series, 25, Chastina 1, 194198 [in Ukrainian].

28. Malolitneva, V.K. Lillemjae, O.E. (2019). Gorizontal'ni cili u publichnih zakupivljah jak dodatkova pidstava dlja ocinki na vidpovidnist' pravilam derzhavnoï dopomogi [Horizontal targets in public procurement as an additional basis for assessing compliance with state aid rules]. Problemi zakonnosti -Problems of legality, 144 .[in Ukrainian].

29. Derzhavne reguljuvannja zakupivel' v umovah realizacï administrativnoï reformi [State regulation of procurement in the context of administrative reform]. Ivano-Frankivs'kij centr nauki, innovacij ta informatizaciï - Ivano-Frankivsk Center for Science, Innovation and Informatization. Ivano-Frankivs'k [in Ukrainian]. 
30. Zhukov, M.S., Udovika, L.G. (2017). Genezis institutu publichnih zakupivel' v Ukraïni [Genesis of the Institute of Public Procurement in Ukraine]. Aktual'ni problemi reformuvannja suchasnogo zakonodavstva - Current issues of reforming modern legislation, 7-10 [in Ukrainian].

31. Kravchuk, A.O. (2013). Razvitie pravovogo regulirovanija v sfere gosudarstvennoj sobstvennosti v Ukraine (upravlencheskij aspekt) [Development of legal regulation in the field of state property in Ukraine (managerial aspect)]. Vestnik TGU. Gumanitarnye nauki. Pravo. Vypusk - TSU newspaper. Humanities. Right, 4 (120), 376-382 [in Ukrainian]. 